\title{
Comparative assessment of adoption determinants of electronic wallet system by rice farmers in Benue and Taraba States, Nigeria
}

\author{
*Gyata, B.A. \\ Department of Agricultural Education, College of Education, Katsina-Ala, Nigeria
}

\begin{abstract}
Article history:
Received: 6 July 2018

Received in revised form: 17 October 2018

Accepted: 22 October 2018

Available Online: 6

November 2018

\section{Keywords:}

Adoption determinants,

Assessment,

Electronic wallet,

Farmers
\end{abstract}

\section{DOI:}

https://doi.org/10.26656/fr.2017.3(2).132

\begin{abstract}
The Federal Government of Nigeria introduced the electronic wallet system in 2013, to help deliver government subsidized farm inputs directly to farmers. A survey was, therefore, conducted to compare adoption determinants of electronic wallet system by rice farmers in Benue and Taraba States, Nigeria. Both descriptive and inferential statistics were used for data analysis. The results showed among others, that some (36\%) of the respondents had at most a secondary education. Whereas $40 \%$ of the respondents realized an average of less than $\$ 100,000.00$ per annum from their rice farm, $67 \%$ of the respondents did not have extension contact and only $30 \%$ had access to credit. Also, the relative advantage $(\overline{\mathrm{x}}=2.5)$ and relevant content $(\overline{\mathrm{x}}=2.43)$ were the most important determinants of adoption of elan ectronic wallet system in Benue State. In Taraba State, observability $(\overline{\mathrm{x}}=2.88)$ and relative advantage $(\overline{\mathrm{x}}=2.84)$ were the most important factors that determined adoption of electronic wallet system. On constraints affecting adoption of e-wallet system, Epileptic network, EPEP (0.589*), Lack of power supply, LOPS $(0.723 *)$, Distance to the registration centre, DRC $(0.722 *)$, Long queues at the registration centre, LQARC $\left(0.725^{*}\right)$, Distance to the redemption centre, DREC $\left(0.745^{*}\right)$, Insufficient fertilizer supply, IFS $\left(0.697^{*}\right)$, Insufficient seed supply, ISS $\left(0.617^{*}\right)$, Low quality fertilizer supply, LQFS $\left(0.870^{*}\right)$, Low quality seed supply, LQSS $\left(0.540^{*}\right)$, Untimely inputs delivery, UID $(0.783 *)$, Poor Policy Implementation, POPI $(0.632 *)$, High cost of mobile phone/accessories, HCMA $(0.858 * *)$, High cost of air time, HCOAT $(0.889 * *)$, Lack of skills and knowledge in use of GSM, LOSK $(0.699 * *)$ and Lack of transport facilities for collection, LOTF $(0.469 * *)$ were significant constraints that affected the adoption of electronic wallet system. The study concluded that there was a significant difference between respondents in Benue State and their counterparts in Taraba State. It is recommended that Government should step up efforts at ensuring that farm inputs are distributed on time.
\end{abstract}

\section{Introduction}

Several efforts have been made in the past to enhance the output of farmer, in terms of making farm inputs accessible and affordable for the farmers. In spite of the numerous efforts made by the Federal Government by providing farm inputs at a subsidized rate in Nigeria, there are still complaints of fertilizer not reaching all the target farmers every year, even though procurement and distribution increases yearly. This could be attributed to "high level of corruption, insincerity and political interruption in the distribution channels" (Adebo, 2014). It was in view of these constraints that the Federal Government introduced the electronic wallet (e-wallet) system in 2012, with the main goal of ensuring access and affordability of farm inputs by farmers. However, the programme has been underperforming due to low level of awareness by the farmers and insufficient fertilizer and seed supply (Adebo, 2014). Abdullahi (2014) also reported that it took a lot of time to complete the registration of a farmer and cost of mobile phones was high. To alleviate the challenge of the cost of mobile phones, the Federal Government at the inception of the e -wallet system had promised to provide mobile phones to farmers at no cost (Adesina, 2012). The phones have not been supplied as promised. Farmers are still left with the task of purchasing their personal phones (Haruna et al., 2013). These constraints could limit the adoption of the e -wallet system by rice farmers in Benue and Taraba States. The system was terminated by the Federal Government in 2015; only for the same Government to 
reintroduce the scheme after one year with a promise to improve on the scheme.

Several research works had been conducted on the use of the e-wallet system for distribution of farm inputs to farmers in other States of the Federation; for instance, Liverpool-Taise et al. (2013) assessed fertilizer voucher programme in Kano and Taraba States and found out that although participants paid significantly lower prices, timeliness of fertilizer distribution worsened and there was no improvement in fertilizer quality. Similarly, Adebo (2014) carried out an investigative study on the effectiveness of e-wallet practice in grassroots agricultural services delivery in Kwara State, Nigeria and recommended that radio and television broadcasts of the programmes on e-wallet system in various Nigerian local languages should be increased. However, none of these studies had attempted to assess adoption determinants of e-wallet system by rice farmers in Benue and Taraba States. It has, therefore, become imperative to fill this research gap.

Specifically, the objectives of this study were to describe the socio-economic characteristics of rice farmers who adopted electronic wallet system in Benue and Taraba States, to identify the determinants of adoption of electronic wallet system in Benue and Taraba States and to identify the constraints associated with the adoption of electronic wallet system in Benue and Taraba States.

\section{Materials and methods}

This study which adopted cross-sectional survey using a research questionnaire to collect data was carried out in Benue and Taraba States, Nigeria. A total of 325 respondents were selected as sample size using multistage sampling techniques. In total, 311 questionnaires were returned for analysis. Data for this study were analyzed using descriptive statistics, such as frequency, percentages and mean as well as inferential statistics, such as the Mann-Whitney (U) test and Factor analysis. South Texas Art Therapy Association (STATA), version 15 constituted the statistical software used for data analysis.

\section{Results and discussion}

\subsection{Socio-economic characteristics of respondents}

\subsubsection{Age (years)}

Table 1 shows that few $(30 \%)$ respondents in Benue State were aged 41- 50 years. This was followed by those $(28 \%)$ in the age bracket of $31-40$ years. Another $22 \%$ were aged 51-60 years. The mean age of the respondents in Benue State was 44.00 years. In Taraba State, many (34\%) respondents were aged 31- 40 years.
This was followed by those (32\%) in the age bracket of 41-50 years. Another 15\% were aged 51-60 years. The mean age of respondents in Taraba State was 45 years. The result shows in the pooled sample that most (31\%) of the respondents were aged $31-40$ years and only $8 \%$ were more than 60 years old. The pooled mean age was 44.12 years. The result shows in the pooled sample that most (30.55\%) of the respondents were aged 31-40 years and only $8.04 \%$ were more than 60 years old. The pooled mean age was 44.12 years. This result implies that farmers who adopted the electronic wallet system in the study area are matured in age and in their active years which indicates their capacity to adopt innovations and to work, respectively. The result is similar with the result of Ezihe et al. (2016) where the researchers investigated accessibility and repayment of agricultural loan among farmers in Benue State, Nigeria and reported that farmers have a mean age of 46.84 years. In Taraba State, Tijjani, Bakari, Usman and Adebayo (2016) accessing the determinants of adoption of agricultural technologies among rice farmers in Taraba State, Nigeria reported that many $(48 \%)$ respondents were aged $30-49$ years.

\subsubsection{Sex}

The study (Table 1) shows that $73 \%$ of the respondents were male, while $27 \%$ were female in Benue State. In Taraba State, $75 \%$ and $25 \%$ respondents were male and female respectively. The pooled result shows that $74 \%$ of the respondents were male and $27 \%$ were female in the study area. The results suggest that as far as farming activities were concerned, both sexes are willing to adopt agricultural innovations for improved productivity. The male dominance implies the laborious nature of farming activities which are very tedious for female farmers to handle. In assessing farmers' use of new information and communication technologies as sources of agricultural information in Ushongo local government area, Benue state, Nigeria, Okwu and Iorkaa (2011) also reported that majority of their respondents were males. The result is also in consonance with Ani and Baba (2009), who reported that more than $70 \%$ of the farmers who utilized selected electronic mass media as sources of agricultural information in Northern Taraba State, Nigeria were males.

\subsection{Level of Education}

Table 1 shows that $98 \%$ of the respondents had one form of formal education or the other in Benue State. A breakdown shows that majority $(36 \%)$ had secondary education, $27 \%$ had sub-degree education and $18 \%$ had primary education. Another $9 \%$ and $9 \%$ had postgraduate and university education respectively. The mean year of educational level was 12.06 years. In Taraba State, 94\% of the respondents had one form of formal education or 
Table 1. Distribution of respondents based on socio-economic characteristics $(n=311)$

\begin{tabular}{|c|c|c|c|c|c|c|c|c|c|}
\hline \multirow{2}{*}{ Variable } & \multicolumn{3}{|c|}{ Benue State $(n=194)$} & \multicolumn{3}{|c|}{ Taraba State $(n=117)$} & \multicolumn{3}{|c|}{ Pooled $(n=311)$} \\
\hline & $\mathrm{F}$ & $\%$ & $\bar{x}$ & $\mathrm{~F}$ & $\%$ & $\bar{x}$ & $\mathrm{~F}$ & $\%$ & $\bar{x}$ \\
\hline Age (years) & & & 43.62 & & & 44.95 & & & 44.12 \\
\hline $21-30$ & 28 & 14.42 & & 10 & 8.55 & & 38 & 12.21 & \\
\hline $31-40$ & 54 & 27.84 & & 40 & 34.19 & & 94 & 30.23 & \\
\hline $41-50$ & 58 & 29.90 & & 37 & 31.62 & & 95 & 30.55 & \\
\hline $51-60$ & 42 & 21.65 & & 17 & 14.53 & & 59 & 18.97 & \\
\hline$>60$ & 12 & 6.19 & & 13 & 11.11 & & 25 & 8.04 & \\
\hline Sub-total (a) & 194 & 100 & & 117 & 100 & & 311 & 100 & \\
\hline \multicolumn{10}{|l|}{$\operatorname{Sex}$} \\
\hline Male & 141 & 72.68 & & 88 & 75.21 & & 229 & 73.63 & \\
\hline Female & 53 & 27.32 & & 29 & 24.79 & & 82 & 26.37 & \\
\hline Sub-total (b) & 194 & 100 & & 117 & 100 & & 311 & 100 & \\
\hline Level of Education (Years) & & & 12.06 & & & 12.21 & & & 12.12 \\
\hline Non- formal $(0)$ & 4 & 2.06 & & 7 & 5.98 & & 11 & 3.54 & \\
\hline Primary (6) & 35 & 18.04 & & 11 & 9.40 & & 46 & 14.79 & \\
\hline Secondary (12) & 69 & 35.57 & & 42 & 35.90 & & 111 & 35.69 & \\
\hline Sub- Degree (14) & 51 & 26.29 & & 45 & 38.46 & & 96 & 30.87 & \\
\hline University (16) & 17 & 8.76 & & 12 & 10.26 & & 29 & 9.32 & \\
\hline Post-Graduate (17) & 18 & 9.28 & & 0 & 0.00 & & 18 & 5.79 & \\
\hline Sub-total (c) & 194 & 100 & & 117 & 100 & & 311 & 100 & \\
\hline $\begin{array}{l}\text { Average Annual Income } \\
\left(\mathrm{N}^{\prime} \mathbf{0 0 0 . 0 0 )}\right.\end{array}$ & & & 121,264 & & & 294,927 & & & 208,096 \\
\hline$\leq 100$ & 118 & 60.86 & & 06 & 5.13 & & 124 & 39.87 & \\
\hline $101-200$ & 49 & 25.25 & & 32 & 27.36 & & 81 & 26.04 & \\
\hline $201-300$ & 17 & 8.76 & & 38 & 32.46 & & 55 & 17.68 & \\
\hline $301-400$ & 4 & 2.96 & & 18 & 15.39 & & 22 & 7.08 & \\
\hline$>401$ & 6 & 3.07 & & 23 & 19.66 & & 29 & 9.33 & \\
\hline Sub-Total (d) & 194 & 100 & & 117 & 100 & & 311 & 100 & \\
\hline \multicolumn{10}{|l|}{ Extension Contact } \\
\hline Yes & 84 & 43.30 & & 19 & 16.24 & & 103 & 33.12 & \\
\hline No & 110 & 56.70 & & 98 & 83.76 & & 208 & 66.88 & \\
\hline Sub-Total (e) & 194 & 100 & & 117 & 100 & & 311 & 100 & \\
\hline \multicolumn{10}{|l|}{ Access to credit } \\
\hline Yes & 81 & 41.75 & & 13 & 11.11 & & 94 & 30.23 & \\
\hline No & 113 & 58.25 & & 104 & 88.89 & & 217 & 69.77 & \\
\hline Sub-Total (f) & 194 & 100 & & 117 & 100 & & 311 & 100 & \\
\hline
\end{tabular}

the other. A break down shows that $38 \%$ had sub-degree education, $36 \%$ had secondary education and $9 \%$ had primary education. The remaining $10 \%$ had a university education. The mean year of education was 12.21 years. In the pooled result (Table 1), 36\% had secondary education, $31 \%$ had sub-degree, $15 \%$ had primary education, $9 \%$ had university education and only $6 \%$ had a postgraduate education. The remaining $3.54 \%$ had no formal education. The mean year of educational level was 12.12 years. This result implies that there was a relatively high educational standard prevalent among the farmers in the study area. This could be an added advantage for the respondents to quickly understand and adopt innovations in agriculture. According to Akinbile and Ndagbu (2000), education has an important implication particularly for the adoption of new technology and practice. This could have been a reason for the popularity of the Growth Enhancement Support Scheme in the study area. This result is similar to the findings of Bidemi and Clement (2017), in their assessment of perceived training needs of smallholder rice farmers on urea deep placement technology in Benue State, Nigeria. The researchers reported that a significant proportion (42.5\%) of their respondents had secondary school education, Elsewhere, Haruna et al. (2013), assessed ownership and use of mobile phones among farmers in North Senatorial Zone of Kaduna State and reported that $35.0 \%$ of their respondents had a secondary education.

\subsection{Average annual income}

Data in Table 1 shows that the mean income of Benue farmers was $\$ 121,264.00$. In Taraba State, The mean income of Taraba farmers was $\$ 294,927.00$. The pooled mean income of Benue and Taraba farmers was

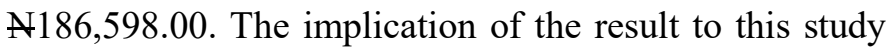
is that, given the right orientation, farmers will be willing and able to at least pay for farm inputs distributed through electronic wallet system, if convinced that it will actually lead to an improvement in their productivity. This is consistent with Odoemenem and Otanwa (2011), where the researchers economically analyzed cassava 
production in Benue State, Nigeria and reported that many $(41.40 \%)$ respondents earned between $\mathrm{N} 50,000$ and $\mathrm{N} 100,000$ in a year.

\subsection{Extension contact}

The pooled result shows that while $66.88 \%$ of the respondents did not have extension contact, $33.12 \%$ of the respondents had extension contact. This result implies that farmers' access to improved farming technologies is limited. Yuguda et al. (2013) also reported that more than 60 percent of their respondents had no contact with extension workers or change agents.

\subsection{Access to credit}

The pooled result shows that $69.77 \%$ of the respondents did not have access to credit while only $30.23 \%$ had access to credit. This suggests that most of the farmers do not have farm credit for production. Low access to credit adversely affects productivity because it leads to low capital investment. This result confirms the finding of Bolarinwa and Fakoya (2011) in their study of the impact of farm credit on farmers' socio-economic status in Ogun State, Nigeria, that only $37.6 \%$ of the farmers secured loan from commercial banks and Nigeria Agricultural and Rural Development Bank.

\subsection{Adoption determinants of electronic wallet system}

Data in Table 2 shows that relative advantage $(\bar{x}$ $=2.5)$ and relevant content $(\bar{x}=2.43)$ were the most important factors that determined adoption of an ectronic wallet system in Benue State. In Taraba State, observability $(\bar{x}=2.88)$ and relative advantage $(\bar{x}=2.84)$ were the most important factors that determined adoption of electronic wallet system. While compatibility $(\bar{x}=1.66)$ and poor income $(\bar{x}=1.87)$ were not important factors that determined adoption of electronic wallet system in Benue State, high cost of mobile phone $(\bar{x}=1.15)$ and poor income $(\bar{x}=1.16)$ were not important determinants of adoption of electronic wallet system in Taraba State. Although, relative advantage $(\bar{x}=2.5)$ was the first major determinant of adoption for Benue State farmers, it was the second most important $(\bar{x}=2.84)$ factor for Taraba State implying that, respondents have actually appreciated electronic wallet system as been better than the previous technologies/ programmes employed for the distribution of farm inputs in the two states. This could be partly responsible for the increased adoption of the system after first year of its implementation. This confirms the findings of Adebo (2014) that $80.00 \%$ of the respondents in Kwara State who participated in GESS programme had better accessibility to improved seeds and fertilizer. The result also shows that poor income was the second least $(\bar{x}=1.87)$ and $(\bar{x}=1.16)$ in Benue State and Taraba State respectively implying that farmers could easily afford the farm inputs distributed through the electronic wallet system. Okwu and Umoru (2008) also reported that a reasonable number of their respondents earn an average income in Apa local government area of Benue State.

\subsection{Constraints associated with the adoption of electronic wallet system in the study area}

Table 3 shows that there were two major categories of constraints associated with adoption of electronic wallet system in the study area namely; factor 1 and factor 2. Though poor economic base of farmers (PEBF) is a socio-economic cum infrastructural constraint, it is not significant because of its low loadings. This implies that the respondents can continuously afford to at least, pay for the inputs distributed to them through the electronic wallet system. This is particularly so as only a few quantities are allocated to each farmer. Similarly, both parochial attitudes (PARA) and Ethnocentric attitudes (ETCA) are Socio-economic cum infrastructural constraints, they are not significant because of their low loadings. This means that most respondents appreciate the existence of electronic wallet system and were willing to continue to obtain their farm inputs through the system. This confirms the findings of Haruna et al. (2013) on the constraints of mobile phone use by farmers, that about $78 \%, 68 \%$ and $62 \%$ of the respondents reported high cost of subscription charges, poor quality of mobile phone and its accessories and power problem respectively to be major constraints.

3.8 Mann-Whitney test for difference in the determinants of adoption of electronic wallet system between rice farmers in Benue and Taraba States

$\mathrm{H}_{\mathrm{o}}$ : There is no significant difference in the determinants of adoption of electronic wallet system between rice farmers in Benue State and Taraba State. The hypothesis was subjected to Mann-Whitney (U) test using STATA 15 statistic software. The following factors were used in assigning scores to farmers; cost of mobile phone, poor income, relevant content, complexity, relative advantage, nearness to redemption centre, observability and compatibility. From the result, $\mathrm{Z}$ value was -2.184 and an Asymptotic p-value (2-tailed) of 0.0289 . Since the p-value is less than 0.05 , it is significant at $5 \%$ level of significance. Therefore, the hypothesis is rejected.

\section{Conclusion}

The study was designed to compare the determinants of adoption of e-wallet system among rice farmers in Benue and Taraba States, Nigeria. The result showed that a higher percentage of the respondents were active and 
Table 2. Rank ordered distribution of adoption determinants of e-wallet system $(n=311)$

\begin{tabular}{|c|c|c|c|c|c|c|c|}
\hline \multirow{2}{*}{ Factor } & \multicolumn{3}{|c|}{ Benue $(n=194)$} & \multirow{2}{*}{ Factor } & \multicolumn{3}{|c|}{ Taraba $(n=117)$} \\
\hline & $\bar{x}$ & SD & Rank & & $\bar{x}$ & SD & Rank \\
\hline Nature of e-wallet & $2.51 *$ & 0.56 & $1^{\text {st }}$ & Observability & $2.88 *$ & 0.37 & $1^{\mathrm{st}}$ \\
\hline Content & $2.43 *$ & 0.57 & $2^{\text {nd }}$ & Nature of e-wallet & $2.84 *$ & 0.55 & $2^{\text {nd }}$ \\
\hline Complexity & $2.30 *$ & 0.74 & $3^{\text {rd }}$ & Distance to redemption centre & $2.81 *$ & 0.47 & $3^{\text {rd }}$ \\
\hline Distance to redemption centre & $2.22 *$ & 0.68 & $4^{\text {th }}$ & Complexity & $2.73 *$ & 0.39 & $4^{\text {th }}$ \\
\hline Observability & $2.22 *$ & 0.67 & $5^{\text {th }}$ & Content & $2.63 *$ & 0.33 & $5^{\text {th }}$ \\
\hline Cost of mobile phone & $2.03 *$ & 0.80 & $6^{\text {th }}$ & Compatibility & 1.80 & 0.39 & $6^{\text {th }}$ \\
\hline Income of farmers & 1.87 & 0.89 & $7^{\text {th }}$ & Income of farmers & 1.16 & 0.39 & $7^{\text {th }}$ \\
\hline Compatibility & 1.66 & 0.80 & $8^{\text {th }}$ & Cost of mobile phone & 1.15 & 0.97 & $8^{\text {th }}$ \\
\hline
\end{tabular}

*Very important determinant $(\overline{\mathrm{x}} \geq 2)$

Table 3. Constraints associated with the use of e-wallet system in the study area

\begin{tabular}{clcc}
\hline S/N & \multicolumn{1}{c}{ Constraints } & ${ }^{\mathrm{a}}$ Factor 1 & ${ }^{\mathrm{b}}$ Factor 2 \\
\hline 1 & High Cost of mobile phone / accessories & 0.231 & $0.858^{\mathrm{b}}$ \\
2 & High Cost of air time & 0.181 & $0.889^{\mathrm{b}}$ \\
3 & Lack of skills and knowledge in use of GSM & 0.259 & $0.699^{\mathrm{b}}$ \\
4 & Epileptic network & $0.589^{\mathrm{a}}$ & 0.212 \\
5 & Lack of power supply & $0.723^{\mathrm{a}}$ & 0.212 \\
6 & Distance to the registration centre & $0.722^{\mathrm{a}}$ & 0.327 \\
7 & Long queues at the registration centre & $0.725^{\mathrm{a}}$ & 0.201 \\
8 & Distance to the redemption centre & $0.745^{\mathrm{a}}$ & 0.271 \\
9 & Insufficient fertilizer supply & $0.697^{\mathrm{a}}$ & 0.202 \\
10 & Insufficient seed supply & $0.617^{\mathrm{a}}$ & 0.166 \\
11 & Low quality fertilizer supply & $0.870^{\mathrm{a}}$ & 0.170 \\
12 & Low quality seed supply & $0.540^{\mathrm{a}}$ & 0.278 \\
13 & Poor economic base of farmers & 0.00697 & -0.021 \\
14 & Poor Policy Implementation & $0.632^{\mathrm{a}}$ & -0.213 \\
15 & Untimely inputs delivery & $0.783^{\mathrm{a}}$ & -0.128 \\
16 & Lack of transport facilities for collection & 0.469 & $0.630^{\mathrm{b}}$ \\
17 & Parochial attitudes & 0.00739 & 0.200 \\
18 & Ethnocentric attitudes & 0.00724 & 0.169 \\
\hline
\end{tabular}

Source: Field Survey, 2017.

Method: Varimax with Kaiser Normalization

${ }^{a}$ Factor 1: Politico-administrative constraints

${ }^{b}$ Factor 2: Socio-economic cum infrastructural constraints

Note: Factors with a value of 0.3 and above are significant and are tagged with "a" under factor 1 . Similary, factors with a value of 0.3 and above are significant and are tagged with "b" under factor 2 . Where a factor is loading high in both columns, the factor is considered to be significant under the column it is loading higher.

mature. Also, majority of the respondents were male who were married. Most of the respondents had secondary education. The respondents earned a reasonable income, even though majority had no access to credit and extension contact. The study finally revealed a significant difference between farmers in Benue State and farmers in Taraba State interns of determinants of adoption of e-wallet system.

From the result obtained, the study concludes that determinants of adoption of e-wallet system differ among respondents in Benue and Taraba States. The determinants for Benue farmers were; Nature of e-wallet, Content, Complexity, Distance to redemption centre, Observability and Cost of mobile phones. The determinants for Taraba farmers were; Observability, Nature of e-wallet, Distance to redemption centre, Complexity and Content.
Based on the findings of this research, the following recommendations were made:

I. Electronic wallet system should continue to be used for the distribution of farm inputs and it should embrace all the farm inputs because of the following reasons, as established by the research:

- Most respondents appreciate the existence of electronic wallet system and they see it has been better than other systems that were used in the distribution

- The respondents were young, active (in their productive age) and had a reasonable level of education and income with which they can buy mobile phones and airtime.

II. Since many respondents did not have access to 
extension contacts, the government should deploy more extension agents in order to improve on the access to farm inputs through the electronic wallet.

\section{References}

Abdullahi, U.A. (2014). A preliminary assessment of fertilizer procurement and distribution under the ewallet scheme. A case study of Doma LGA, Nasarawa State, Nigeria. Nigeria: Nasarawa State University, BSc. Thesis.

Adebo, G.M. (2014). Effectiveness of e-wallet practice in grassroots agricultural services delivery in Nigeria -a case study of Kwara State growth enhancement support scheme. Journal of Experimental Biology and Agricultural Science, 2(4), 1-20.

Adesina, O. (2012). Address at the 36th Session of the International Fund Agricultural Development Governing Council. Retrieved on October 2, 2015 from http://www.ifad.org/events/gc/36/speech/ nigeria.htm. 31 .

Akinbile, L.A. and Ndagbu, A.A.T. (2000). Poverty level and poverty alleviation strategies of farm families in Michika L. G. A. of Adamawa State, Nigeria. Journal of Economics and Rural Development, 14(2), 103.

Bidemi, O.A. and Clement, A.O. (2017). Perceived training needs of smallholder rice farmers on urea deep placement technology in Benue State, Nigeria. Asian Journal of Agricultural Extension, 19(2), 4.

Bolarinwa, K.K. and Fakoya, E.O. (2011). Impact of farm credit on farmers socio-economic status in Ogun State, Nigeria. Journal of Social Science, 26 (1), 68

Ezihe, J.A.C., Akpa, J.A. and Ayoola, J.B. (2016). Accessibility and repayment of agricultural loan among farmers in Benue State, Nigeria. IOSR Journal of Agriculture and Veterinary Science, 9(8), 39-41. https://doi.org/10.9790/2380-0908023946

Haruna, S.K., Jamilu, A.A., Abdullahi, A.Y. and Murtala, G. (2013). Ownership and use of mobile phones among farmers in North Senatorial Zone of Kaduna State. Journal of Agricultural Extension, 17 (2), 47-54. https://doi.org/10.4314/jae.v17i2.7

Liverpool-Tasie, S.L.O., Banful, A.B. and Olaniyan, B. (2013). An assessment of the 2012 fertilizer voucher program in Kano and Taraba, Nigeria. NSSP Working Paper 17. Washington, D.C.: International Food Policy Research Institute.

Odoemenem, I.U. and Otanwa, L.B. (2011). Economic Analysis of Cassava Production in Benue State, Nigeria. Current Research Journal of Social Sciences. Current Research Journal of Social
Sciences, 3(5), 406-411

Okwu, O.J. and Iorkaa, T.I. (2011). An assessment of farmers' use of new information and communication technologies as sources of agricultural information in Ushongo Local Government Area, Benue State, Nigeria. Journal of Sustainable Development in Africa, 13(2), 45.

Okwu, O.J. and Umoru, B.I. (2008). Study of women farmers agricultural information needs and accessibility: a case study of Apa Local Government Area of Benue State, Nigeria. African Journal of Agricultural Research, 4(12), 1404-1409.

Yuguda, R.M., Girei, A.A. Dire, B. and Salihu, M. (2013). Socio-economic factors and constraints influencing productivity among cassava farmers in Taraba State, Nigeria. International Journal of Advances in Agricultural Science and Technology, 1 (1), 9 . 